expectation of pleasuruble information, he is suddenly blindfolded, and finds himself surrounded and overmatched by hostile persons. Neither, if his story be false, is he likely to have gone to the Mansion House to make an affidavit, nor to have repeated his desire, when told that a deliberately wrong affirmation would involve six months' imprisonment. Lastly, it was inevitable that the Post-office authorities should, however tardily, adopt all necessary precautions; but it was not incumbent on them to treat an undoubtedly valuable witness of intended mischief with contumely and injustice, at any rate until he had been proved a false witness.

I am, Sir, yours obediently,

Clapton, April 23rd, 1883.

D. DE BERDT HOVELL.

\section{DUBLIN HOSPITALS AND THE IRISH PROFESSION.}

To the Editor of THE LANCET.

SIR,-We are always saying that there is no profession so defrauded as ours, and yet we every day assist in defrauding one another. What is the use of talk without action? Silence would be more dignified than old womanly grumblings. I have, however, a hope that there is a growing awakening as to the absolute necessity for substituting deeds for mere words, and co-operation and energetic action for isolated and barren protests. Here, now, are two instances where the profession has been wronged. Within the last two weeks two wealthy females, who had arranged to be operated on by me for tumours, were both subsequently induced to go up to the Mater Misericordix Hospital, Dublin, in order that they might be operated on for nothing, thus obtaining the services of our profession gratuitously, and at the same time defrauding two poor persons of those beds which were designed exclusively for them. I notified the facts to one of the staff of the Mater, and called on them, in their own interests quite as much as in mine, to insist on the removal of the parties to lodgings, so as to charge them proper fees, or to send them home. That letter led to no action whatever, and I now bring the matter under the cognisance of the Irish profession at large, and I would remind them that it is because these cases are samples, not exceptions, and that these acts of injustice are of long standing, are practised by every hospital in Dublin, and embrace within their sphere every doctor in Ireland, that it is hopeless to attempt to deal with them, and that we provincials must continue to lie under the wrong and the loss. I tell my provincial brethren that if they ouly but will it they can put down thoroughly, promptly, and decisively this grievous injustice to themselves. I know that many provincial doctors do not care to operate, and that many of these, misled by a short-sighted jealousy, very often prefer to smuggle even wealthy patients into Dublin hospitals. I would meet such local jealousies by having the consultant allow the local man to operate where the latter brings him in, and where he is willing to operate, and when he is not willing I would have his presence invariably sought as a right. I think that such a course as this would go far to get rid of the provincial help at present given to the injurious system complained of. I will undertake to propound a practical scheme, and would invite as many provincial men as possible to form a society for meet. ing the action of those Dublin physicians and surgeons who would persist in keeping wealthy patients, whether medical or surgical, in hospital after having been informed of the means of the parties. One of us should be charged to report every improper case to the senior surgeon or physiciaa of the hospital, into which such parties might smuggle them selves, and to duly advertise the medical problic of the action taken thereon by the different hospital staffs. In this matter medical students could render important service, and looking at the fact that it will be their interests to-morrow, as it is ours to-day, to stamp this practice out, I cannot permit myself to doubt that they will be found so wanting in shrewdness as to hesitate to give every assistance in their power. Let every offending Dublin hospital be convinced that there is at least a large body of provincials who are thoroughly in earnest, and we shall put an end to one of the most grievous systems of injustice that our profession has now to complain of. Once, again, let me appeal to my brethren to wake up to some kind of perception of the pecuniary loss which they sustain, and to the fact that it is in their power to put an end to such losses. It is not operation cases alone that are smuggled into Dublin hospitals, but wealthy medical cases are daily admitted into them also. There is not the slightest use, $I$ fear, for an individual to appeal to the metropolitan staffs. They were publicly ppealed to again and again by me years ago, and in vain. Cashel, April 20th, 1883. $\mathrm{am}$, Sir, yours truly, Thomas LaAfFan.

\section{CRANIUM HOLDERS.}

To the Editor of THE LANCET.

SrR,-If Dr. Ormsby, whose letter on this subject appears in your issue of April 14th, will take the trouble to refer to The Lancet of 1858 , vol. ii., p. 50, he will there find a communication, which you were so good as to publish for me, entitled "A Description of a Form of Craniotome for Postmortem Examinations," which will, I think, effectually dispose of the claim of priority of invention in such instruments. The cranium holder there depicted is still made by Messrs. Wood and Son, surgical instrument makers of this city, and has this advantage over others recently brought before the profession for a similar purpose, that it can be folded up when not in use so as to occupy very little space in a case of post-mortem instruments of ordinary dimensions.

When I published this description of my invention, I showed at the same time an improved form of saw for dividing the bones of the cranium, so constructed as to prevent, as far as possible, in the hurry of a post-mortem inspection, any injury being done to the surface of the brain by sawing too deeply. In this age of invention it is often very difficult to know what has actually been done by our predecessors, and, I feel confident, Dr. Ormsby was not aware that the principle of his invention had so long since been anticipated by yours, \&c.,

Manchester, April 24th, 1883.

\section{THE CONTAGIOUS DISEASES ACTS.}

\section{To the Editor of The LANCET.}

SIR,-As I find that my silence during the discussion on Mr. Stansfeld's resolution has not unnaturally been misinterpreted by my professional brethen, who expected me to say something in defence of the committee of which I had been a member, and in favour of Acts which, I believe, to have worked well, will you allow me a few words of explanation? I rose several times in the course of the evening to catch the Speaker's eye, but without success; and when I endeavoured, at the close of the debate, to say a few words, the "evident sense of the House" inflicted the "Clôture" on my intended remarks. At that late hour I only wished to express, in the briefest possible terms, my emphatic dissent from the opinion enunciated by the Chancellor of the Exchequer, to the effect that the Acts could be successfully carried out minus the compulsory examinations. - I am, Sir, your obedient servant, April 25th, 1833.

Robert FARQUHARson.

\section{"FOREIGN DEGREES AND THE MEDICAL BILL." \\ To the Editor of THE LANCET.}

SIR, - I have been in communication with the Lord President of the Council on the above subject, and have this morning received the enclosed letter, which states clearly his Lordship's opinion of the status of foreign graduates as affected by the Bill. I shall therefore be obliged if you will kindly insert it in your next issue.

I am, Sir, your obedient servant,

F. ERnest Pocock, M.D.,

Hon. Sec. Brussels Medical Graduater' Association. St. Mrark's-road, North Kensington, W., April 21th, 1883.

$$
\text { [COPY.] }
$$

Council Office, 23rd April, 1883.

SIR,-I am directed by the Lord President of the Council to acknowledge the receipt of your letter of the $2 /$ st instant, and to inform you that, in his Lordship's opinion, the Medical Act Amendment Bill now befure Parliament enables 
any person who is legully using any title at the present moment to continue to use the same, and that the Bill does not affect any existing right.

I am, Sir, your obedient servant, (Signed) CII,

F. Ernest Pocock, Ksq., M.D., The Liin
North Kensington, W.

P.S. - I have just heard from a medical friend who had written to Lord Cranbrook on the subject that, at the suggestion of the latter, the followiug has been inserted in the Bill :-Clause 69. "This Act shall not make illegal the uses by any person, after the passing thereof, of any medical title which he was actually using, and was entited to use, at the date of the passing of this Act."-F. E. P.

April 25th.

\section{THE PROPOSED HOSPITAL FOR NORTH LONDON.}

To the Editor of THE LANCET.

SIR,-Circulars have been distributed in and around North London, announcing a meeting to be held at the Highbury Athenæum under distinguished lay (not medical) patronage on behalf of the proposed new hospital for North London. Will you allow me as a practitioner in North London to protest in your valuable journal against such a scheme, and for the following reasons:-1. We are already amply supplied with hospitals. We have the Great Northern, the Royal Free, the Tottenham, the North London, and other institutions suitable for the treatment and reception of in- or out-patients. The Holloway and North Islington Dispensary Charity has four branches in North London for visiting and attending those who are unable to pay. Besides which there are several special hospitals and dispensaries. 2. It is as much as the existing charities can get along, owing to the paucity of subscriptions, consequently we may infer thatanother rival hospital would not only probably find itself in a constant sitate of impecuniosity, but it would most certainly cripple those already existing. 3. The proposal, so far as I can understand it, does not receive sanction from the majority of medical practitioners resident in North London. It is a fact that there are already a large number of "Medicals" who find it very hard "to make both ends meet" as it is ; and, though possibly a few of the long resident practitioners in the neighbourhood may encourage the scheme, they are apt, unintention. ally, of course, to forget that their junior brethren are to a great extent dependent upon the class of people who would frequent the hospital. I refer not to the very poor, but to those who are well able to pay for their attendance.

Not being a good platform speaker, I am unable to submit these ideas of mine at the meeting, but if there are any gentlemen connected with our profession who have the time or inclination to propose amendments to the resolutions, they would be not only doing a service to a hard-working and poorly paid profession, but would show that there is no necessity for another hospital. I may add that the meet. ing takes place at four P.M. on Saturday, April 28th. April, 1883

JUNIOR.

\section{LARGE FEMORAL HERNIA. To the Editor of THE LANCET.}

SIR,-On reading the account given by Mr. Bernard Pitts in THE LANCET of April 7th, of the rupture of a large hernial sac, I am reminded of a somewhat similar case that $I$ witnessed many years ago ; and $I$ am tempted to seek at your hands a record of it in your pages. It will be becoming in $m e$, in the first place, to acknowledge that the facts I am about to relate are entirely from memory; but I think it will be conceded that the circumstances were such as were well calculated to make an indelible impression on a young mind; and $I$ will venture to assert that the leading features of the case are as fresh in my recollection as if they had only happened yesterday. The history I am about to relate may be relied on as strictly and literally correct, so far as it goes. The case occurred as far back as the year 1819, at which time I was a pupil of the late Mr. Thomas Roberts (a surgeon of high standing at that time) at Bangor, North Wales. The patient was an Irishwoman, about thirty. five years of age, the wife of a discharged soldier, and the mother of three or four children. She had hernia (femoral) of many years standing, which was only partially reducible, and which had latterly acquired such a size as to be pendulous One day, after having been standing over the wash-tub in the back kitchen for many hours consecutively, one of the children who was at play with the others in the front room had a fall and screamed violently. The mother, alarmed at this, rushed into the front room, picked the child up in her arms, and sat hurriedly on a low stool. In the act of doing this the tumour slipped between her thighs, rested on the stool, and she sat heavily upon it. The consequence was the parietes of the tumour gave way with a rent of about four inches, and instantly the contents were lying on the floor. Mr. Roberts was immediately sent for, and in his absence I went. I found her lying on the floor, her countenance was blanched, with an exprezsion of great anxiety and alarm. On lifting her dress, I was horrified to find an immense mass of intestine resting on the front of her thighs, extending from the aperture in the sac to some inches below her knees. She told me she had placed them in this position herself. Mr. Roberts soon arrived, and, shortly after, Mr. Hagh Jones, another practitioner in the town. Some brandy-and-water was given her, her legs were crossed, her dress drawn tightly round them, and in this state she was carried upstairs, undressed, and put to bed. By this time she had rallied considerably from the state of collapse in which I found her. She did not appear to r ealise in the least the impending danger of her condition, and I well remember how struck and astonished I was at the flippant way in which she talked of her domestic concerns and future management. The two surgeons on the contrary, viewed the case as perfectly hopeless, and told the husband she could not possibly live eight-and-forty hours. The next step, however, that of replacing the intes. tines in the sac, was proceeded with, and in doing this, acting upon their preconceived prognosis, but little trouble was taken to deprive them of the dirt that adhered to them off the floor, and the soap off her under garments ; their manipulation also was equally devoid of care or delicacy. In this way, and in this manner, the intestines were replaced in the sac, the edges of the wound were brought together and secured by an uninterrupted suture; an opiate was administered, and in this state she was left.

Strange as it may appear this woman recovered, and her recovery was unattended from first to last with a single symptom of an untoward character. The wound healed by the first intention, and in about three weeks she was able to resume her usual domestic duties, and was alive and well in 1822, when I left the neighbourhood.

Lewes, April, 1883.

I am, Sir, yours truly,

J. JONES

EDINBURGH.

(From our own Correspondent.)

\section{EXTENSION OF THE EDINBURGH UNIVERSITY BUILDINGS.}

A PUBLIC meeting, convened by the Lord Provost at the request of the acting committee for the extension and improvement of the Edinburgh University buildings, was held in the Queen-street Hall on March 28th. The Earl of Wemyss proposed, and Sir Lyon Playfair, M.P., seconded the following resolution, which was carried with applause:- "That the recent continuous increase in the prosperity and efficiency of the University of Edinburgh renders it highly necessary that its New Medical School should be completed." The Lord Advocate moved, and Mr. A. G. Balfour, M.P., seconded the second resolution, which was also unanimously adopted, viz.:- "That as the University of Edinburgh still labours under the want of a hall for conferring degrees, conducting examinations, and holding meetings of its members, strenuous efforts should now be made to get that want supplied." Lord Moncreiff moved the third resolution, which was seconded by the Marquis of Tweeddale, and unanimously carried - viz, "That the tercentenary of the University of Edinburgh is an especially appropriate occasion for appealing to its friends and old pupils, not only in Scotland, but over the world, to contribute funds for the completion of its buildings." Sir Alexander Grant proposed the fourth resolution, which was 